\title{
Selecting technological alternatives for regulatory compliance towards emissions reduction from shipping: An integrated fuzzy multi-criteria decision-making approach under vague environment
}

\author{
Khanh Q. Buia*, Aykut I. Ölçer b, Momoko Kitadab and Fabio \\ Ballinib
}

aDepartment of Technology and Safety, The Arctic University of Norway, Troms $\phi$, Norway

Department of Nautical Science, Faculty of Navigation, Vietnam Maritime University, Hai Phong, Vietnam;

bMaritime Energy Management Specialization, World Maritime University, Malmö, Sweden

*Corresponding author: Khanh Q. Bui

Email address: khanh.q.bui@uit.no / buiquangkhanh@vimaru.edu.vn

\section{Abstract}

Due to the increasing pressure from stricter environmental regulations to reduce emissions in shipping, the maritime industry has been striving for finding more effective measures. Existing measures are often not enough to comply with new regulations. Amongst various alternative measures, it is not easy for decision-makers (shipowners and operators) to choose the most suitable alternative measure as it involves with multicriteria decision-making (MCDM) where the prioritization of a number of alternatives vis-à-vis multiple criteria evaluation is undertaken. Further challenges on such analysis are the lack of information as well as its subjectivity and/or the inconsistency. This study proposes an integrative fuzzy MCDM method that combines fuzzy Analytic Hierarchy Process (AHP) and fuzzy Technique for Order Performance by Similarity to Ideal Solution (TOPSIS) for the selection of technological alternatives for regulatory compliance under vague environment. Nine criteria within three sustainability spheres (social-economic-environmental sphere) were analyzed and evaluated as regards four possible alternatives. The weights of these aspects and criteria were determined by the fuzzy AHP meanwhile alternatives were prioritized by the fuzzy TOPSIS.

According to the outputs of the proposed decision-making framework, the study revealed that Low-Sulphur Fuels is the best suitable alternative for regulatory compliance. The following alternatives are Methanol, Scrubbers and Liquefied natural gas (LNG) in order. Sensitivity analysis was conducted to tell us that the proposed 
framework is robust. This proposed method will be potentially applicable to other fields where decisions are required to make under vague information conditions.

Keywords: International shipping, Emissions reduction, Selection of technological alternatives, Multi-criteria decision-making, Fuzzy AHP and Fuzzy TOPSIS.

\section{Introduction}

International shipping has been criticized as contributing roughly $3 \%$ of annual global anthropogenic carbon dioxide $\left(\mathrm{CO}_{2}\right)$ emissions.1 Furthermore, global anthropogenic sulphur dioxides $\left(\mathrm{SO}_{2}\right)$ and nitrogen oxides $\left(\mathrm{NO}_{x}\right)$ emissions from the same sector at the figure of $4-9 \%$ and $15 \%$ respectively are also serious concerns.2 Air emissions from shipping are regulated in the Annex VI of the International Convention for the Prevention of Pollution from Ships (MARPOL) by the International Maritime Organization (IMO). As regards the concerted effort for reducing greenhouse gas (GHG) emissions, the International Maritime Organization (IMO) introduced two mandatory mechanisms from both technical and operational aspects namely Energy Efficiency Design Index (EEDI) and Ship Energy Efficiency Management Plan (SEEMP), coming into force from 1 January 2013. The former is the technical standard which applies for new-built vessels where the latter is an energy efficient improvement plan required on board existing vessels during its life-cycle operation.3 The IMO has also adopted a resolution to at least halve GHG emissions by 2050 in comparison with 2008 while striving for phasing them out entirely.4 Regulation 14 of the MARPOL Annex VI has regulated $\mathrm{SO}_{\mathrm{x}}$ emissions from shipping, setting the limit of $0.1 \%$ on sulphur content in fuel oil for vessels operate in designated Emission Control Areas (ECAs) from January 2015. It should be noted here that the upcoming global sulphur cap that requires sulphur content limit of $0.5 \%$ will go into effect from 1 January 2020.5 With the view of ensuring a consistent enforcement and implementation of this limit, the IMO has adopted the carriage ban on non-compliant fuel, entering into force from March 2020.6 Regulation 13 of the MARPOL Annex VI has regulated NOx emissions from ships. $\mathrm{NO}_{\mathrm{x}}$ Tier III standards entered into force since 1 January 2016 in ECAs (except for the Baltic Sea and the North Sea) for all new-built ships with keel-laying on or after 1 January 2016. Nevertheless, the IMO approved these areas as NOx-ECA, taking effect from 1 January 2021.7

Due to the increasingly stringent requirements concerning air emissions reduction, the maritime industry has been forced to find alternative measures. There are a wide variety of possible options that can be considered to meet above-mentioned requirements. One of the options is switching to Low-Sulphur Fuels (e.g., marine diesel oil (MDO) and marine gas oil (MGO)). The second alternative would be running on heavy fuel oil (HFO) along with the installation of exhaust gas cleaning systems (maritime scrubbers). Utilizing Liquefied Natural Gas (LNG) by new machinery installation or retrofit has also attracted the interests of maritime operators. Switching to Methanol is also a good potential alternative for reducing emissions from shipping. Nevertheless, it is not easy for decision-makers (shipowners and operators) to choose the best suitable alternative as it is a MCDM problem in which the evaluation of a number of alternatives vis-à-vis multiple criteria is taken into consideration. Further challenge on such analysis is the lack of information as well as its subjectivity and/or the inconsistency.8 In order to overcome these problems, the paper presents the development of an integrative fuzzy MCDM approach by the combination of the fuzzy AHP and the fuzzy TOPSIS technique. The fuzzy AHP was deployed for attaining the weights of aspects and criteria while the fuzzy TOPSIS was employed for evaluating 
and prioritizing alternatives. The proposed fuzzy approach was exemplified with a real case study by engaging ship-owners as decision makers.

The next section reviews literature review on MCDM methods in the maritime research domain while section 3 presents criteria for sustainability evaluation for technological alternatives. Afterwards, the integrated fuzzy MCDM method is proposed in section 4. A real case study in section 5 is presented to draw the exemplification of the proposed approach. The final section is the discussion and conclusion.

\section{MCDM methods in the maritime research domain}

In recent literature, the application of TOPSIS method proposed by Shih et al.9 can be well-observed in addressing the MCDM issue. The fundamental principle of this method is to select the most preferred alternative that has shortest Euclidean distance from the positive ideal solution (PIS) and farthest Euclidean distance from the negative ideal solution (NIS). The PIS maximizes the benefit criteria as well as minimizing the cost criteria. Generally, the classical MCDM methods represent the criteria weights and the alternatives ratings as crisp values. Nonetheless, it is inadequate to use crisp values to stimulate decision-making problem in many cases. As a result, an enhanced variant of TOPSIS namely fuzzy TOPSIS is suggested to tackle this issue. The fuzzy TOPSIS evaluates the criteria weights and alternatives ratings by fuzzy linguistics evaluation based on fuzzy set theory.10, 11 There are several benefits of the TOPSIS and fuzzy TOPSIS technique. First of all, human choices and preferences are embodied in the logical way. In addition, the computation process might be programmed easily. Moreover, the number of stages in the method remains the same irrespective of the number criteria. A further advantage is that they reveal a scalar value that represents the most preferred and the least preferred alternatives at the same time.12

The literature has witnessed that the fuzzy TOPSIS encounters great difficulties in obtaining the criteria weights and keeping consistency of judgment. These difficulties can be grappled with the integration of fuzzy TOPSIS with other technique (i.e. fuzzy AHP). The integrative approach may have the possibility of obtaining the criteria weightings under a fuzzy environment that may involve unquantifiable, inaccurate, incomplete information.8 The classical AHP13 identifies the criteria weights or alternatives weights by utilizing a hierarchy paradigm including goal, major factor, subfactor and alternatives. However, the main drawback of AHP is that the application of a discrete scale of 1-9 could not determine the priorities of different criteria precisely by virtue of imprecision and uncertainties of human judgments. In order to overcome such problem, the fuzzy AHP technique that incorporates the fuzzy set theory 10,11 into the classical $\mathrm{AHP}_{13}$ is deployed to depict human perception and preferences. To be more specific, the fuzzy AHP which applies the fuzzy comparison ratio might be able to deal with the ambiguity in the model. Criteria and alternatives are evaluated by means of linguistic emphasis and fuzzy numbers. Therefore, the fuzzy AHP precisely reflects human thinking.

In literature, several studies have proposed different methods to address MCDM problem especially for the evaluation of air pollution prevention measures for regulatory compliance in shipping. Schinas and Stefanakos 14 presented the ANP technique for complying with the MARPOL Annex VI requirement. By using a subjective generic methodology, Yang et al.15 developed an evaluation model for selecting $\mathrm{NO}_{\mathrm{x}}$ and $\mathrm{SO}_{\mathrm{x}}$ emission control solutions. Ölçer and Balliniı employed TOPSIS method for the 
evaluation of the trade-off solutions towards cleaner seaborne transportation. Ren and Lützen17 presented a generic model which incorporates the fuzzy AHP and VIKOR techniques for the selection of the emissions reduction alternative technologies for ships. Wang and Nguyen18 developed an integration of fuzzy QFD and fuzzy TOPSIS method for prioritizing mechanism of low-carbon shipping measures. Beşikçi et al.19 applied the fuzzy AHP method to prioritize ship operational energy efficiency measures in accordance with SEEMP. Ren and Lützen20 proposed a MCDM method by combining Dempster-Shafer theory and the trapezoidal fuzzy AHP for the selection of sustainable alternative energy source for shipping. Ren and Liang21 presented an integrated method combining fuzzy logarithmic least squares and fuzzy TOPSIS for measuring the sustainability of alternative marine fuels. The improved Gaussian fuzzy AHP method was proposed by Sahin and Yip22 for the shipping technology selection for dynamic capability. Each of above approach has its strengths and weaknesses. Nevertheless, these research studies have used either fuzzy AHP or fuzzy TOPSIS techniques. This study proposes an integrative fuzzy MCDM approach by the way of integrating the fuzzy AHP method into the fuzzy TOPSIS method.

\section{Criteria for sustainability evaluation for technological alternatives}

In this section, the evaluation for technological alternatives for emissions reduction from ships has been considered into two levels: aspects and criteria. Based on the concept of sustainable development, the selection of aspects is defined as three pillars that are visualized as overlapping circles, aiming at achieving economic prosperity, environmental health, and social responsibility simultaneously.23 The selection of criteria is derived from literature review such as technical reports and scientific publications. The economic aspect consists of capital cost, operational cost and lifecycle cost. The environmental aspect comprises the impact on $\mathrm{SO}_{\mathrm{x}}$ emissions reduction, the impact on $\mathrm{NO}_{\mathrm{x}}$ emissions reduction, the impact on GHG emissions reduction, and the impact on PM emissions reduction. Externalities and government \& industry support are criteria belonging to social aspects. The decision-makers are dealing with the problem of selecting the best alternative with regard to aspects and criteria evaluation as presented in Figure 1. 


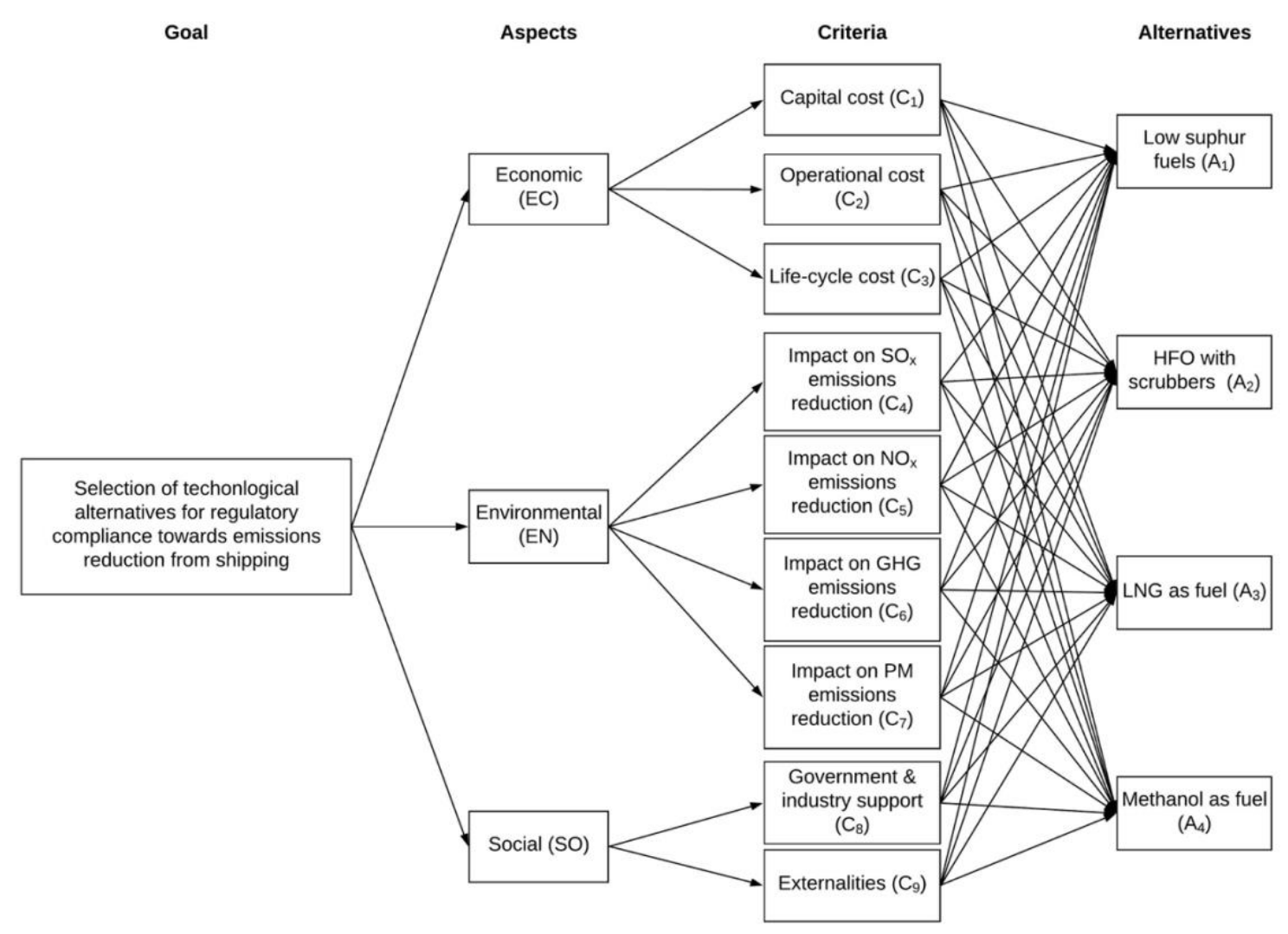

Figure 1. Hierarchical decision-making framework of selecting alternatives for regulatory compliance towards emissions reduction from shipping

\subsection{Economic aspect}

- Capital cost

The capital cost mentions the costs for retrofitting existing vessel to operate alternative fuels (e.g., LNG or Methanol) or the costs for the installation of new technological devices on board such as scrubber.24

- Operational cost

The operational cost comprises fuel price, maintenance costs, and consumable costs. 24

- Life-cycle cost

The life-cycle cost refers to the costs for building, manning, operating and maintaining over the lifespan of a ship. 25

\subsection{Environmental aspect}

- Impact on $\mathrm{SO}_{x}$ emissions reduction 
It mentions the influence of using proposed options on the reduction of $\mathrm{SO}_{\mathrm{x}}$ emissions that consist of $\mathrm{SO}_{2}$ and $\mathrm{SO}_{3}$ emissions. For many years, $\mathrm{SO}_{2}$ is one of the air pollutants that result in acidification. The sulphate particles from $\mathrm{SO}_{\mathrm{x}}$ exert negative effects on human health, visibility and climate. 26

- Impact on $\mathrm{NO}_{\mathrm{x}}$ emissions reduction

It mentions the influence of proposed options on the reduction of $\mathrm{NO}_{\mathrm{x}}$ emissions that consist of $\mathrm{NO}$ and $\mathrm{NO}_{2}$ emissions. When $\mathrm{NO}_{\mathrm{x}}$ is emitted into the air, it brings about various negative impacts on environment (e.g., acidification, eutrophication).27 Additionally, the formation of ground-level ozone and secondary particulate matter is partly attributed to $\mathrm{NO}_{\mathrm{x}}$ emissions.28 "NOx emissions from international shipping are a direct contribution to eutrophication of inland and marine waters and terrestrial habitats, and to the formation of secondary particulate matter affecting health". 29

\subsection{Social aspect}

- Government \& industry support

This criterion expresses the attitudes of government and public support to the adoption of technological alternatives onboard the ships to meet emissions reduction standards and requirements. 21

- Externalities

An externality occurs when the economic or social activities of a group of people affect another group and this influence is not completely accountable, or reimbursed for, by the former group.30 The shipping industry has produced negative externalities in the form of air pollution to natural habitats and ecosystems.31

It is important to realize that there are inconsistencies or vagueness in terms of the value of several criteria as regards alternatives given by published studies as presented in Table 1-3. For example, the effects of scrubber on $\mathrm{NO}_{\mathrm{x}}$ emissions reduction are still unknown.32 Likewise, it is inconsistent in the effects of scrubber on PM emissions reduction, some studies point at no reduction while others indicate the reduction of $75-90 \%$ PM emissions but lacks transparency.33 Another problem could be found is that there is a lack of information concerning some criteria (e.g., life-cycle cost and externalities) in respect of alternatives in the literature. Moreover, some of criteria tend to be described as intervals instead of crisp numbers. By way of illustration, the figures of environmental criteria (e.g., reduction of $\mathrm{SO}_{x}, \mathrm{NO}_{x}, \mathrm{CO}_{2}$, and $\mathrm{PM}$ emissions) are likely to be depicted in intervals format. In addition, it is not easy to quantify the economic criteria (e.g., capital cost and operational cost) since they tend to fluctuate by virtue of unpredictable nature of oil market. Apart from that, social criteria (e.g. government \& industry support) is unquantifiable. 
Table 1. Economic evaluation for technological alternatives

\begin{tabular}{|c|c|c|c|c|}
\hline $\begin{array}{l}\text { Economic } \\
\text { Aspect }\end{array}$ & Low-Sulphur Fuels & $\begin{array}{l}\text { HFO with } \\
\text { scrubber }\end{array}$ & LNG & Methanol \\
\hline 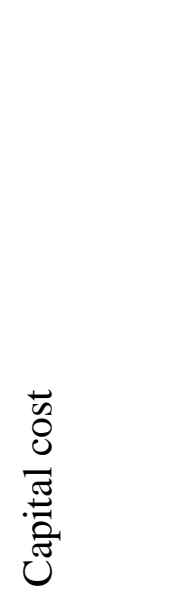 & $\begin{array}{l}\text { Considered to be } \\
\text { negligible. } 34 \text { Incur the } \\
\text { lowest capital cost, } \\
\text { compared to that of } \\
\text { scrubber installation } \\
\text { and LNG utilization. } 35\end{array}$ & $\begin{array}{l}\text { Ranges from } € \\
2 \text { to } 8 \text { million } \\
\text { per vessel, } \\
\text { determined by } \\
\text { the type of } \\
\text { vessel and } \\
\text { scrubber.35 }\end{array}$ & $\begin{array}{l}\text { Higher than the } \\
\text { combination of } \\
\text { scrubber and } \\
\text { SCR system.36 } \\
\text { Around 10-20\% } \\
\text { higher in } \\
\text { comparison with } \\
\text { traditional drive } \\
\text { systems.37 } \\
\text { Estimated to be } \\
€ 4-6 \text { million.38 }\end{array}$ & $\begin{array}{l}\text { Equivalent to } \\
\text { costs for } \\
\text { installing } \\
\text { scrubber and } \\
\text { SCR } \\
\text { technology } \\
\text { and below } \\
\text { LNG } \\
\text { investment } \\
\text { costs.39 }\end{array}$ \\
\hline 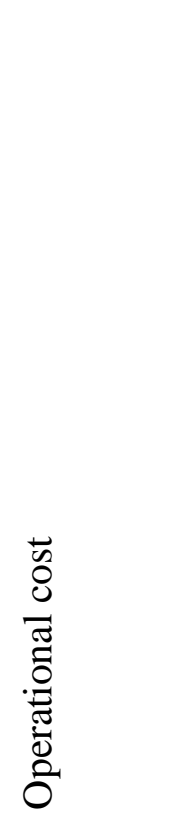 & $\begin{array}{l}\text { Significantly more } 30 \text { - } \\
50 \% \text { expensive than } \\
\text { the conventional } \\
\text { fuels. } 36,40 \\
\text { The MGO price is } \\
\text { predicted to increase } \\
\text { in the short-term in } \\
\text { short-sea shipping in } \\
\text { ECAs.41 } \\
\text { Estimated to rise by } \\
\text { about } 87 \% \text { attributed } \\
\text { to the expense of } \\
\text { refining and } \\
\text { converting to low- } \\
\text { sulphur fuel.34 }\end{array}$ & $\begin{array}{l}\text { Ranges from } € \\
320 \text { to } 580 \text { per } \\
\text { tonne sulphur } \\
\text { dioxide. } 42 \\
\text { Could be } \\
\text { about } 1-3 \% \text { of } \\
\text { capital cost per } \\
\text { year. } 43\end{array}$ & $\begin{array}{l}\text { About } 6,1 \% \\
\text { lower than that } \\
\text { of HFO in } \\
2016.44 \\
\text { The future price } \\
\text { is unpredictable } \\
\text { due to the } \\
\text { unavailability of } \\
\text { global market } \\
\text { for natural gas } \\
\text { and LNG marine } \\
\text { bunkering. } 45\end{array}$ & $\begin{array}{l}\text { Competitive } \\
\text { with other } \\
\text { emissions } \\
\text { compliant } \\
\text { fuels, depends } \\
\text { on the fuel } \\
\text { price } \\
\text { differentials.39 }\end{array}$ \\
\hline 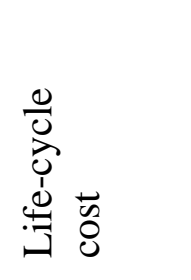 & Lack of information & $\begin{array}{l}\text { Cheaper than } \\
\text { that of low- } \\
\text { sulphur fuel in } \\
\text { the longer } \\
\text { term.34 }\end{array}$ & $\begin{array}{l}\text { Lower than that } \\
\text { of oil-fuelled } \\
\text { vessels. } 44\end{array}$ & $\begin{array}{l}\text { Lack of } \\
\text { information }\end{array}$ \\
\hline
\end{tabular}


Table 2. Environmental evaluation for technological alternatives

\begin{tabular}{|c|c|c|c|c|}
\hline $\begin{array}{l}\text { Environ } \\
\text {-mental } \\
\text { Aspect }\end{array}$ & Low-Sulphur fuels & HFO with scrubber & LNG & Methanol \\
\hline 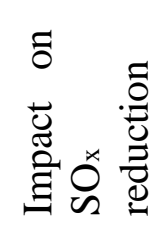 & $\begin{array}{ll}\text { Low } & \mathrm{SO}_{\mathrm{x}} \\
\text { emissions.23 } & \end{array}$ & $\begin{array}{l}\text { Effective reduction } \\
\text { of } 98 \% \quad \mathrm{SO}_{\mathrm{x}} \\
\text { emissions.23 }\end{array}$ & $\begin{array}{l}\mathrm{SO}_{\mathrm{x}} \text { emissions is } \\
\text { virtually zero. } 32\end{array}$ & $\begin{array}{l}\text { Negligible } \\
\text { SOx } \\
\text { emissions.39 }\end{array}$ \\
\hline 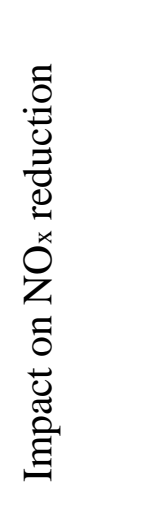 & $\begin{array}{l}\text { MGO provides a } \\
\text { few percent on } \\
\mathrm{NO}_{\mathrm{x}} \text { emissions } \\
\text { reduction. } \\
\mathrm{MGO} \text { with SCR } \\
\text { can reduce } \mathrm{NO}_{\mathrm{x}} \\
\text { emissions of } 80 \% \text {, } \\
\text { compared to } \mathrm{HFO} \\
\text { engines.42 }\end{array}$ & $\begin{array}{l}\mathrm{NO}_{\mathrm{x}} \text { emissions } \\
\text { reduction is still } \\
\text { unknown. (Burel et } \\
\text { al., 2013); } \\
\text { Need additional } \\
\text { after-treatment like } \\
\text { SCR which reduces } \\
\mathrm{NO} \text { emissions by } \\
87 \% .42\end{array}$ & $\begin{array}{l}\text { Reduction of } 75- \\
90 \% \\
\text { emissions } \\
\text { compared to } \mathrm{HFO} \\
\text { engines.23 }\end{array}$ & $\begin{array}{l}\mathrm{NO}_{\mathrm{x}} \text { emissions } \\
\text { level is low, } \\
\text { might be in } \\
\text { line with Tier } \\
\text { III NOx } \\
\text { compliance. } 23\end{array}$ \\
\hline 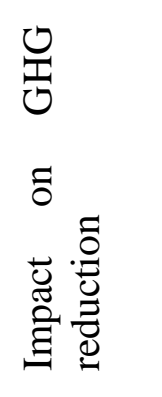 & No decrease & No decrease & $\begin{array}{lr}\text { Reduction of } & 20- \\
25 \% & \mathrm{CO}_{2} \\
\text { emissions } & \\
\text { compared } & \text { to } \\
\mathrm{HFO} / \mathrm{MGO} / \\
\text { MDO but result } \\
\text { in Methane slip.23 }\end{array}$ & $\begin{array}{l}\text { Reduce GHG } \\
\text { emission if } \\
\text { produced from } \\
\text { biomass.23 }\end{array}$ \\
\hline 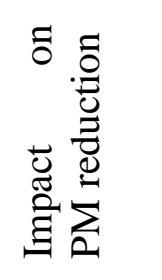 & $\begin{array}{l}\text { Reduces } \\
\text { emissions }\end{array}$ & $\begin{array}{l}\text { Reduction of } 75- \\
90 \% \text { PM emissions } \\
\text { but lacks } \\
\text { transparency.33 }\end{array}$ & $\begin{array}{l}\text { Reduction of } 90- \\
95 \% \\
\text { emissions } \\
\text { compared } \\
\text { MGO.23 }\end{array}$ & $\begin{array}{l}\mathrm{PM} \\
\text { production is } \\
\text { negligible.24 }\end{array}$ \\
\hline
\end{tabular}


Table 3. Social evaluation for technological alternatives

\begin{tabular}{|c|c|c|c|c|}
\hline $\begin{array}{l}\text { Social } \\
\text { aspect }\end{array}$ & $\begin{array}{l}\text { Low- } \\
\text { Sulphur } \\
\text { fuels }\end{array}$ & $\begin{array}{l}\text { HFO with } \\
\text { scrubber }\end{array}$ & LNG & Methanol \\
\hline 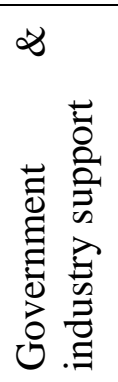 & $\begin{array}{l}\text { A short- } \\
\text { term } \\
\text { solution. } 46\end{array}$ & $\begin{array}{llr}\text { There } & \text { are } \\
\text { currently } & 983 \\
\text { vessels } & \text { with } \\
\text { scrubbers } & \\
\text { installed or in } \\
\text { order as of } 31 \\
\text { May 2018.47 }\end{array}$ & $\begin{array}{l}\text { There are currently } \\
247 \quad \text { confirmed } \\
\text { LNG fueled ships } \\
\text { and } 110 \text { additional } \\
\text { LNG ready } \\
\text { ships.48 }\end{array}$ & $\begin{array}{l}\text { Attractive low-carbon } \\
\text { alternative. } 23 \\
\text { Methanol, produced } \\
\text { from biomass, is } \\
\text { regarded as viable fuel } \\
\text { for ships.49 }\end{array}$ \\
\hline 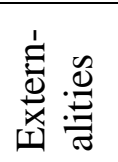 & \multicolumn{4}{|c|}{ Lack of information } \\
\hline
\end{tabular}

Therefore, it should be noted that this is a multi-criteria decision making analysis that involves the prioritization of multiple technologies alternatives vis-à-vis multiple criteria evaluation conducted under vague environment. As aforementioned illustration, the vague environment can be understood that there is a problem of inconsistent and incomplete information concerning several criteria in respect of alternatives. Furthermore, several criteria with respect to alternatives are not in the form of crisp numbers, not easy to quantify or unquantifiable. The following section proposes the integrated fuzzy MCDM method in order to overcome these problems.

\section{Method}

In this section, fuzzy set theory will be discussed with some basic definitions of fuzzy numbers. Afterwards, the integrative fuzzy MCDM method will be presented in more detail.

\subsection{Fuzzy set theory}

According to Dubois and Prade50, Kaufmann and Gupta51 the concept of fuzzy numbers can be defined as follows:

Definition 1: A real fuzzy number $A$ is described as any fuzzy subset of the real line $R$ with membership function $f_{A}$, which has the following properties:

$f_{A}$ is a continuous mapping from $R$ to the closed interval $[0,1]$.

$f_{A}(x)=0$, for all $x \in(-\infty, a]$.

$f A$ is strictly increasing on $[a, b]$.

$f_{A}(x)=1$, for all $x \in[b, c]$.

$f A$ is strictly decreasing on $[c, d]$.

$f_{A}(x)=0$, for all $x \in(d, \infty]$. 
where $a, b, c$ and $d$ are real numbers. Unless elsewhere specified, assuming $A$ is convex and bounded (i.e., $-\infty<a, d<\infty$ ).

Definition 2: The fuzzy number $A=[a, b, c, d]$ is a trapezoidal fuzzy number if its membership function is given by:

$$
f_{A}(x)=\left\{\begin{array}{cc}
f_{A}^{L}(x), & a \leq x \leq b \\
1, & b \leq x \leq c \\
f_{A}^{R}(x), & c \leq x \leq d \\
0, & \text { otherwise }
\end{array}\right.
$$

where $f_{A}^{L}(x)$ and $f_{A}^{R}(x)$ are the left and right membership functions of $A$, correspondingly.

When $b=c$, the trapezoidal fuzzy number is reduced to a triangular fuzzy number and can be denoted by $A=(a, b, d)$. Hence, triangular fuzzy numbers are special cases of trapezoidal fuzzy numbers.

Definition 3: The distance between fuzzy triangular numbers

Let $A=\left(a_{1}, b_{1}, d_{1}\right)$ and $B=\left(a_{2}, b_{2}, d_{2}\right)$ be two triangular fuzzy numbers. The distance between them is given using the vertex method by:

$$
d(A, B)=\sqrt{\frac{1}{3}\left[\left(a_{1}-a_{2}\right)^{2}+\left(b_{1}-b_{2}\right)^{2}+\left(d_{1}-d_{2}\right)^{2}\right]}
$$

\section{Definition 4: $\alpha$-cuts}

The $\alpha$-cuts of fuzzy number $A$ can be defined as $\left.A^{\alpha}=\left\{x \mid f_{A}(x) \geq \alpha\right)\right\}, \alpha \in$ $[0,1]$ where $A^{\alpha}$ is a nonempty bounded closed interval contained in $R$ and can be denoted by $A^{\alpha}=\left[A_{l}^{\alpha}, A_{u}^{\alpha}\right]$ where $A_{l}^{\alpha}$ and $A_{u}^{\alpha}$ are its lower and upper bounds, respectively. For example, if a triangular fuzzy number $A=(a, b, d)$, then the $\alpha$-cuts of $A$ can be expressed as follows:

$$
A^{\alpha}=\left[A_{l}^{\alpha}, A_{u}^{\alpha}\right]=[(b-a) \alpha+a,(b-d) \alpha+d]
$$

Definition 5: Arithmetic operations on fuzzy numbers

Given fuzzy numbers $A$ and $B$ where $A, B \in R^{+}$, the $\alpha$-cuts of $A$ and $B$ are $A^{\alpha}=$ $\left[A_{l}^{\alpha}, A_{u}^{\alpha}\right], B^{\alpha}=\left[B_{l}^{\alpha}, B_{u}^{\alpha}\right]$, correspondingly.

The operations of $A$ and $B$ can be expressed by the interval arithmetic:

$$
\begin{array}{ll}
(A \oplus B)^{\alpha}=\left[A_{l}^{\alpha}+B_{l}^{\alpha}, A_{u}^{\alpha}+B_{u}^{\alpha}\right], & (A \oslash B)^{\alpha}=\left[\frac{A_{l}^{\alpha}}{B_{l}^{\alpha}}, \frac{A_{u}^{\alpha}}{B_{u}^{\alpha}}\right], \\
(A \ominus B)^{\alpha}=\left[A_{l}^{\alpha}-B_{l}^{\alpha}, A_{u}^{\alpha}-B_{u}^{\alpha}\right], & (A \otimes r)^{\alpha}=\left[A_{l}^{\alpha} \cdot r, A_{u}^{\alpha} \cdot r\right], \quad r \in R^{+} \\
(A \otimes B)^{\alpha}=\left[A_{l}^{\alpha} \cdot B_{l}^{\alpha}, A_{u}^{\alpha} \cdot B_{u}^{\alpha}\right], &
\end{array}
$$




\subsection{The integrated fuzzy MCDM method}

The proposed integrated fuzzy MCDM method is demonstrated in Figure 2. One should note here that the involvement from experts plays pivotal role throughout the proposed method. The identification of criteria and alternatives from literature (e.g., technical reports and peer-reviewed papers) can be consulted with experts by means of interviews. Afterwards, the proposed method will go through the following stages and steps.

(1) Stage 1. Expert's preferences aggregation

With a view to aggregating the preferences in the important weights of aspects/ criteria assessed by a group of experts, pairwise comparison matrix then can be developed. In this respect, we applied arithmetic operations.52

Let $z_{i j t}=\left(a_{i j t}, b_{i j t}, c_{i j t}\right), i=1,2, \ldots, m ; j=1,2, \ldots, n ; t=1,2, \ldots, l$ be the suitability important weight assigned to one aspect/ criterion over another aspect/ criterion by decision maker $D M_{t}$. The averaged suitability important weight $z_{i j}=$ $\left(a_{i j}, b_{i j}, c_{i j}\right)$ can be calculated as follows:

$$
\begin{aligned}
& z_{i j}=\left(a_{i j}, b_{i j}, c_{i j}\right)=\frac{1}{l} \otimes\left(a_{i j 1} \oplus a_{i j 2} \oplus \ldots \oplus a_{i j t} \oplus \ldots \oplus a_{i j l}\right) \\
& a_{i j}=\frac{1}{l} \sum_{t=1}^{l} a_{i j l}, b_{i j}=\frac{1}{l} \sum_{t=1}^{l} b_{i j l}, c_{i j}=\frac{1}{l} \sum_{t=1}^{l} g_{i j l} .
\end{aligned}
$$




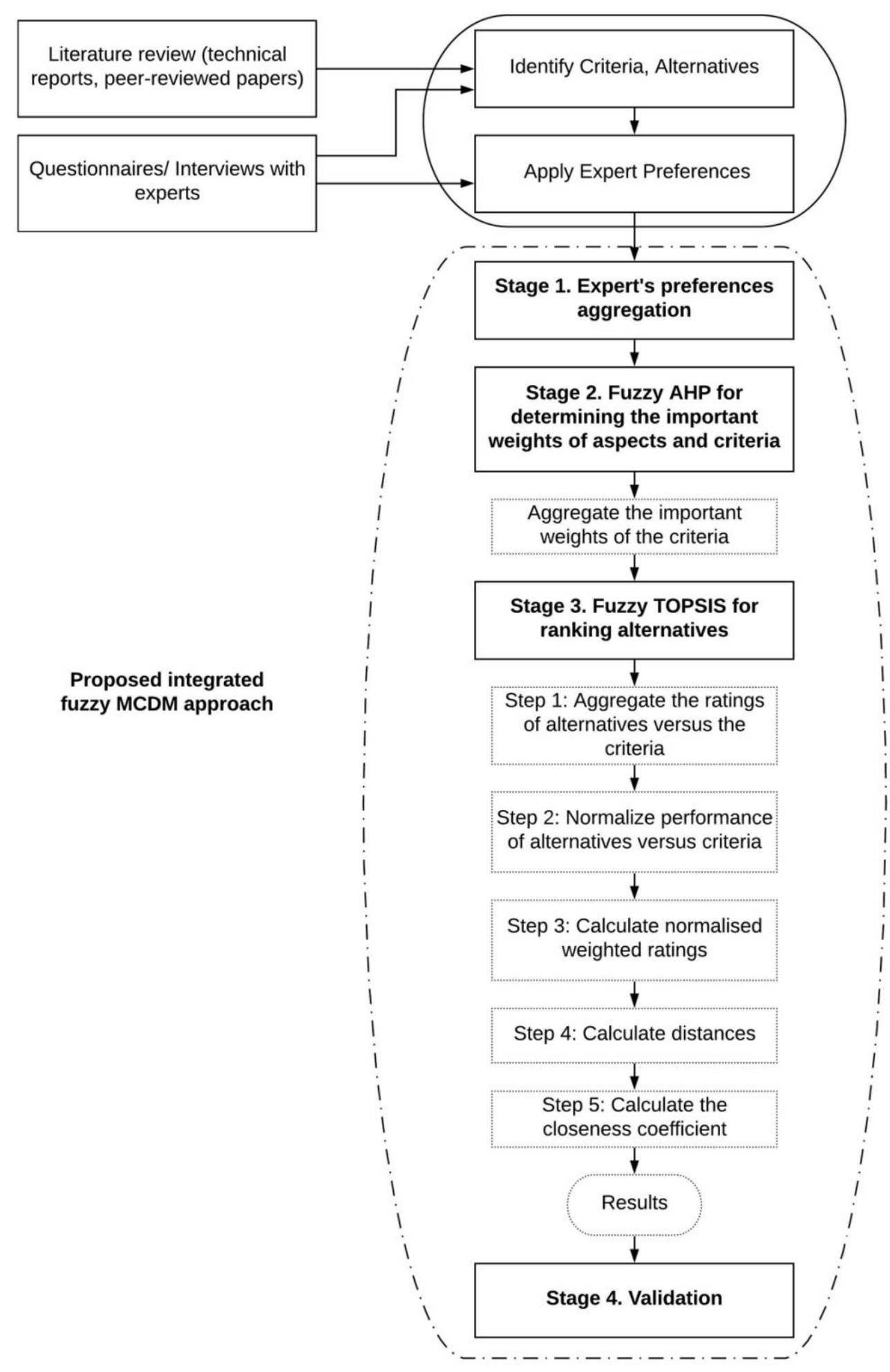

Figure 2. Schematic diagram of the proposed integrated fuzzy MCDM approach

(2) Stage 2. Fuzzy AHP for obtaining the important weights of aspects and criteria

The extent analysis methodology proposed by Chang 53 was applied to obtain the important weights of aspects and criteria. 
- Fuzzy synthetic extent calculation

Let $X=\left\{x_{1}, x_{2}, x_{3}, \ldots, x_{n}\right\}$ be an object set, and $U=\left\{u_{1}, u_{2}, u_{3}, \ldots, u_{n}\right\}$ be a goal set. Each object is taken and an extent analysis for each goal $g_{i}$ is performed respectively. Thus, the $m$ extent analysis values for each object can be calculated, and are denoted as follows:

$M_{g i}^{1}, M_{g i}^{2}, \ldots, M_{g i}^{m} i=1,2, \ldots, n$

where all the $M_{g i}^{j}(j=1,2, \ldots, m)$ are triangular fuzzy numbers.

With respect to the $j$ th object for $m$ goals, the value of fuzzy synthetic extent is defined as:

$$
S_{i}=\sum_{j=1}^{m} M_{g i}^{j} \otimes\left[\sum_{i=1}^{n} \sum_{j=1}^{m} M_{g i}^{j}\right]^{-1}
$$

where $\sum_{j=1}^{m} M_{g i}^{j}=\left(\sum_{j=1}^{m} l_{j}, \sum_{j=1}^{m} m_{j}, \sum_{j=1}^{m} u_{j}\right),(j=1,2, \ldots, m),(i=1,2, \ldots, n)$

- Comparison of fuzzy values

The degree of possibility of two triangular fuzzy numbers $M_{1}=\left(l_{1}, m_{1}, u_{1}\right) \geq$ $M_{2}=\left(l_{2}, m_{2}, u_{2}\right)$ is defined as follows:

$$
V\left(M_{1} \geq M_{2}\right)=\underbrace{S U P}_{x \geq y}\left[\min \left(\mu_{M_{1}}(x), \mu_{M_{2}}(y)\right)\right]
$$

when a pair $(x, y)$ exists such that $x \geq y$ and $\mu_{M_{1}}(x)=\mu_{M_{2}}(y)=1$ then we have $V\left(M_{2} \geq M_{1}\right)$. Because $M_{1}$ and $M_{2}$ are convex fuzzy numbers, the membership degree of possibility is identified as follows:

$$
V\left(M_{1} \geq M_{2}\right)=\operatorname{hgt}\left(M_{1} \cap M_{2}\right)=\mu_{M_{2}}(d)
$$

where $d$ is the ordinate of the highest intersection point D between $\mu_{M_{1}}$ and $\mu_{M_{2}}$, as shown in Figure 3. When $M_{1}=\left(l_{1}, m_{1}, u_{1}\right)$ and $M_{2}=\left(l_{2}, m_{2}, u_{2}\right)$, then $\mu_{M_{2}}(d)$ is given as follows:

$$
\mu_{M_{2}}(d)=\left\{\begin{array}{c}
1, \quad \text { if } m_{1} \geq m_{2} \\
0, \quad \text { if } l_{2} \geq u_{1} \\
\frac{\left(l_{2}-u_{1}\right)}{\left(l_{2}-u_{1}\right)+\left(m_{1}-m_{2}\right)}, \quad \text { otherwise }
\end{array}\right.
$$

To compare $M_{1}$ and $M_{2}$ we need both the values of $V\left(M_{1} \geq M_{2}\right)$ and $V\left(M_{2} \geq\right.$ $\left.M_{1}\right)$ 


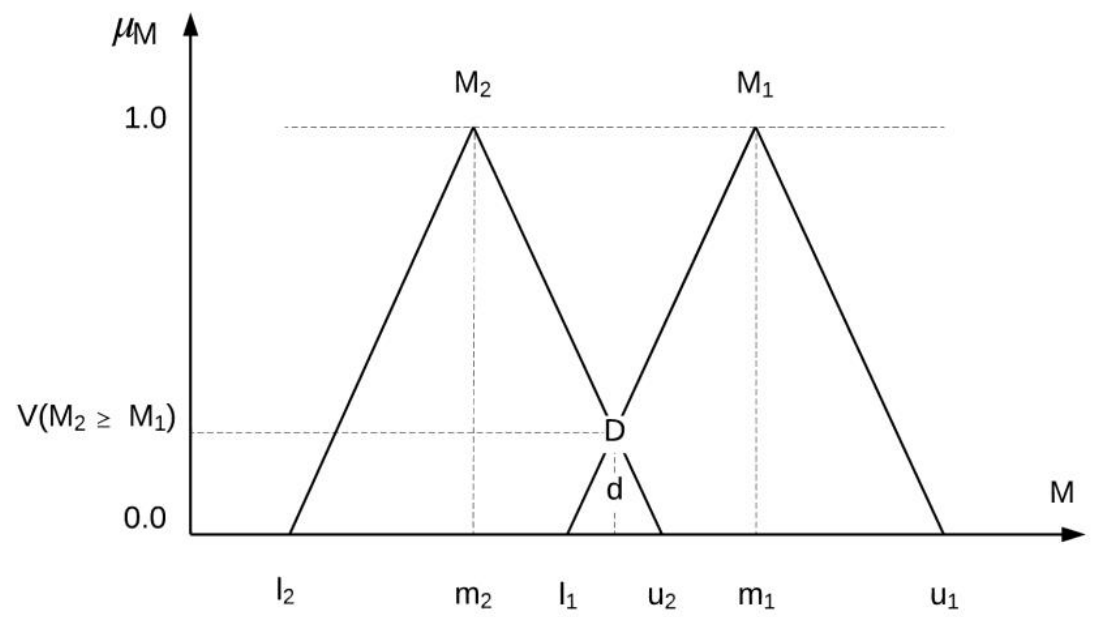

Figure 3. Intersection between $M_{1}$ and $M_{2}$

- Priority weight calculation

The degree possibility of convex fuzzy number to be greater than $k$ convex fuzzy numbers $M_{i}(i=1,2, \ldots k)$ can be expressed as follows:

$$
\begin{array}{r}
V\left(M \geq M_{1}, M_{2}, \ldots, M_{k}\right)=V\left[\left(M \geq M_{1}\right) \text { and }\left(M \geq M_{2}\right) \text { and } \ldots\left(M \geq M_{k}\right)\right] \\
V\left(M \geq M_{1}, M_{2}, \ldots, M_{k}\right)=\min V\left(M \geq M_{i}\right) i=1,2, \ldots, k
\end{array}
$$

If

$$
d^{\prime}\left(A_{i}\right)=\min V\left(S_{i} \geq S_{k}\right) k=1,2, \ldots, n ; k \neq i
$$

Then the weight vector is given by

$$
W^{\prime}\left(A_{i}\right)=\left(d^{\prime}\left(A_{1}\right), d^{\prime}\left(A_{2}\right), \ldots d^{\prime}\left(A_{n}\right)\right)^{T}
$$

Here $A_{i}(i=1,2, \ldots, n)$ are $n$ elements

- Calculation of normalized weight vector

Via normalization of $W^{\prime}\left(A_{i}\right)$

$$
d\left(A_{i}\right)=\frac{d^{\prime}\left(A_{i}\right)}{\sum_{i=1}^{n} d^{\prime}\left(A_{i}\right)}
$$

Then the normalized weight vectors are obtained as follows:

$$
W\left(A_{i}\right)=\left(d\left(A_{1}\right), d\left(A_{2}\right), \ldots d\left(A_{n}\right)\right)^{T}
$$

Where $W$ is a non-fuzzy number. 
(3) Stage 3. Fuzzy TOPSIS for ranking alternatives

According to Chen12, the fuzzy TOPSIS procedure is discussed as follows:

- Step 1. Aggregate the ratings of alternatives versus criteria

Let $\quad x_{i j t}=\left(e_{i j t}, f_{i j t}, g_{i j t}\right), i=1,2, \ldots, m ; j=1,2, \ldots, n ; t=1,2, \ldots, k$ be the suitability rating assigned to alternative $A_{i}$, by decision maker $D M_{t}$, for criterion $C_{i}$. The averaged suitability rating $x_{i j}=\left(e_{i j}, f_{i j}, g_{i j}\right)$ can be calculated as follows:

$x_{i j}=\left(e_{i j}, f_{i j}, g_{i j}\right)=\frac{1}{k} \otimes\left(x_{i j 1} \oplus x_{i j 2} \oplus \ldots \oplus x_{i j t} \oplus \ldots \oplus x_{i j k}\right)$

where $e_{i j}=\frac{1}{k} \sum_{t=1}^{k} e_{i j k}, f_{i j}=\frac{1}{k} \sum_{t=1}^{k} f_{i j k}, g_{i j}=\frac{1}{k} \sum_{t=1}^{k} g_{i j k}$.

- Step 2. Normalize performance of alternatives versus criteria

In order to ensure compatibility between average ratings and average weightings, the average ratings are normalized into comparable scales. Assume that $r_{i j}=\left(a_{i j}, b_{i j}, c_{i j}\right)$ is the performance of alternative $i$ on criteria $j$. Then the normalized value can be denoted as follows:

$$
\begin{aligned}
& x_{i j}=\left(\frac{a_{i j}}{c_{j}^{*}}, \frac{b_{i j}}{c_{j}^{*}}, \frac{c_{i j}}{c_{j}^{*}}\right), \quad j \in B \\
& x_{i j}=\left(\frac{a_{j}^{-}}{c_{i j}}, \frac{a_{j}^{-}}{b_{i j}}, \frac{a_{j}^{-}}{a_{i j}}\right), \quad j \in C
\end{aligned}
$$

where $a_{j}^{-}=\min _{i} a_{i j}, c_{j}^{*}=\max _{i} c_{i j}, i=1, \ldots, m ; j=1, \ldots, n . \quad B$ is for benefit criterion whereas $C$ is for cost criterion.

- Step 3. Calculate normalized weighted rating

The normalized weighted ratings $G_{i}$ can be computed by multiplying the importance weights of criteria $w_{j}$ with the values of the normalized average rating $x_{i j}$ as follows:

$$
G_{i}=x_{i j} \otimes w_{j}, i=1, \ldots, m ; j=1, \ldots, n
$$

- Step 4. Calculate distances 
The fuzzy positive ideal solution (FPIS) $A^{+}$and fuzzy negative ideal solution (FNIS) $A^{-}$can be obtained as follows:

$$
\begin{aligned}
& A^{+}=(1.0,1.0,1.0) \\
& A^{-}=(0.0,0.0,0.0)
\end{aligned}
$$

The distance of each alternative $A_{i}, i=1, \ldots, m$ from the FPIS $A^{+}$and NPIS $A^{-}$ is calculated as follows:

$$
\begin{aligned}
& d_{i}^{+}=\sqrt{\sum_{i=1}^{m}\left(G_{i}-A^{+}\right)^{2}} \\
& d_{\mathrm{i}}^{-}=\sqrt{\sum_{\mathrm{i}=1}^{\mathrm{m}}\left(\mathrm{G}_{\mathrm{i}}-\mathrm{A}^{-}\right)^{2}}
\end{aligned}
$$

where $d_{i}^{+}$accounts for the shortest distance of alternative $A_{i}$ and $d_{i}^{-}$accounts for the furthest distance of alternative $A_{i}$.

- Step 5. Calculate the closeness coefficient

The closeness coefficient of each alternative $C C_{i}$ is obtained as follows:

$$
C C_{i}=\frac{d_{i}^{-}}{d_{i}^{+}+d_{i}^{-}}
$$

A higher value of the closeness coefficient shows that an alternative is closer to FPIS and further from FNIS at the same time. The alternatives prioritization or ranking (from the most preferred to the least preferred) can be obtained based on $C C_{i}$.

(4) Stage 4. Validation

Sensitivity analysis is one of the most useful tools to see whether or not the results are robust. The concept of this technique is to change the priority weights mutually and the behaviors of alternatives expressed by $C C_{i}$ are then changed accordingly.54 A number of experiments will be undertaken and each of them shall generate a new scenario for the purpose of determining which criterion has the most substantial impact upon the proposed approach. 


\section{Case study}

The applicability of the proposed integrative fuzzy MCDM was drawn by a real case study. Four alternative technologies for regulatory compliance towards reducing emissions from ships including Low-Sulphur Fuels ( $\left.A_{1}\right)$, HFO with scrubbers $\left(\mathrm{A}_{2}\right)$, LNG (A3) and Methanol (A4) were analyzed. Nine criteria discussed in previous section can be classified into cost or benefit criteria. The former means the larger, the less preference whereas the latter means the larger, the more preference. 9 The cost criteria are Capital cost $\left(\mathrm{C}_{1}\right)$, Operational cost $\left(\mathrm{C}_{2}\right)$, Life-cycle cost $\left(\mathrm{C}_{3}\right)$ and Externalities $\left(\mathrm{C}_{9}\right)$. The benefit criteria are Impact of $\mathrm{SO}_{x}$ emission reduction $\left(\mathrm{C}_{4}\right)$, Impact of $\mathrm{NO}_{\mathrm{x}}$ emission reduction ( $\left.\mathrm{C}_{5}\right)$, Impact of $\mathrm{GHG}$ emission reduction ( $\left.\mathrm{C}_{6}\right)$, Impact of PM emission reduction $(\mathrm{C} 7)$.

The data were obtained by undertaking in-depth interviews with experts from one of the largest shipping companies based in Sweden. The experts hold managementlevel positions in their organization and have been working in the shipping sector for a long time. The first expert has technical background and expertise on developing regulations and standards at international levels (e.g., the IMO and EU). The second expert has worked for a number of shipping companies and has a deep understanding of maritime business. The third expert has background in environmental science and has broad experience in environmental management and sustainable business development in ports and shipping industry. As previously mentioned, the proposed criteria were decided based on the judgement as well as preferences of these experts. In this regard, they can add or delete criteria in each aspect according to the actual situations. They were asked to evaluate respectively the important weights of selected aspects and criteria then ratings alternatives based on their preferences. With the purpose of deciding the different important weights of each aspect, criterion, each interviewee was asked to make pairwise comparison in respect of different aspect, criterion using fuzzy linguistic evaluation variables by Chen 12 as illustrated in Table 4. 


\begin{tabular}{lll}
\hline Linguistic terms for importance & Code & $\begin{array}{c}\text { Triangular fuzzy numbers } \\
\boldsymbol{M}=(\boldsymbol{l}, \boldsymbol{m}, \boldsymbol{u})\end{array}$ \\
\hline Just equal & JE & $(1.0,1.0,1.0)$ \\
Equal importance & EQI & $(1.0,1.0,3.0)$ \\
Weak importance & WI & $(1.0,3.0,5.0)$ \\
Strong importance & SI & $(3.0,5.0,7.0)$ \\
Very strong importance & VSI & $(5.0,7.0,9.0)$ \\
Extremely importance & EXI & $(7.0,9.0,9.0)$ \\
Reciprocals & & The reciprocals of above fuzzy numbers \\
\end{tabular}

(1) Stage 1. Expert's preferences aggregation

The decision makers were asked to assign the important weight of one aspect over another aspect (by pairwise comparison). Table 5 shows the results of the preferences of experts towards aspects while Table 6 shows the transformation of these results into triangular fuzzy number.

Table 5. Preferences of decision makers towards aspects

\begin{tabular}{|c|c|c|c|c|}
\hline Aspect & $\begin{array}{l}\text { Decision } \\
\text { makers }\end{array}$ & $\mathrm{EC}$ & EN & $\mathrm{SO}$ \\
\hline \multirow{3}{*}{$\mathrm{EC}$} & $\mathrm{DM}_{1}$ & $\mathrm{JE}$ & VSI & VSI \\
\hline & $\mathrm{DM}_{2}$ & $\mathrm{JE}$ & SI & EQI \\
\hline & $\mathrm{DM}_{3}$ & $\mathrm{JE}$ & SI & VSI \\
\hline \multirow{3}{*}{ EN } & $\mathrm{DM}_{1}$ & & $\mathrm{JE}$ & EQI \\
\hline & $\mathrm{DM}_{2}$ & & $\mathrm{JE}$ & SI \\
\hline & $\mathrm{DM}_{3}$ & & $\mathrm{JE}$ & SI \\
\hline \multirow{3}{*}{$\mathrm{SO}$} & $\mathrm{DM}_{1}$ & & & $\mathrm{JE}$ \\
\hline & $\mathrm{DM}_{2}$ & & & $\mathrm{JE}$ \\
\hline & $\mathrm{DM}_{3}$ & & & $\mathrm{JE}$ \\
\hline
\end{tabular}


Table 6. Transforming the preferences of decision makers towards aspects into fuzzy triangular numbers

\begin{tabular}{lllll}
\hline Aspect & Decision makers & EC & EN & SO \\
\hline \multirow{2}{*}{$\mathrm{EC}$} & $\mathrm{DM}_{1}$ & $(1.0,1.0,1.0)$ & $(5.0,7.0,9.0)$ & $(5.0,7.0,9.0)$ \\
\cline { 2 - 5 } & $\mathrm{DM}_{2}$ & $(1.0,1.0,1.0)$ & $(3.0,5.0,7.0)$ & $(1.0,1.0,3.0)$ \\
\cline { 2 - 5 } & $\mathrm{DM}_{3}$ & $(1.0,1.0,1.0)$ & $(3.0,5.0,7.0)$ & $(5.0,7.0,9.0)$ \\
\hline \multirow{2}{*}{$\mathrm{EN}$} & $\mathrm{DM}_{1}$ & & $(1.0,1.0,1.0)$ & $(1.0,1.0,3.0)$ \\
\cline { 2 - 5 } & $\mathrm{DM}_{2}$ & & $(1.0,1.0,1.0)$ & $(3.0,5.0,7.0)$ \\
\cline { 2 - 5 } & $\mathrm{DM}_{3}$ & & $(1.0,1.0,1.0)$ & $(3.0,5.0,7.0)$ \\
\hline \multirow{2}{*}{$\mathrm{SO}$} & $\mathrm{DM}_{1}$ & & & $(1.0,1.0,1.0)$ \\
\cline { 2 - 5 } & $\mathrm{DM}_{2}$ & & $(1.0,1.0,1.0)$ \\
\cline { 2 - 5 } & $\mathrm{DM}_{3}$ & & $(1.0,1.0,1.0)$ \\
\hline
\end{tabular}

The aggregation of experts' preferences is performed with the help of Eq. (5). Table 7 presents the aggregated fuzzy comparison matrix of three aspects.

Table 7. Aggregated fuzzy comparison matrix of aspect

\begin{tabular}{llll}
\hline Aspects & EC & EN & SO \\
\hline EC & $(1.00,1.00,1.00)$ & $(3.67,5.67,7.67)$ & $(3.67,5.00,7.00)$ \\
EN & $(0.13,0.18,0.27)$ & $(1.00,1.00,1.00)$ & $(2.33,3.67,5.67)$ \\
SO & $(0.14,0.20,0.27)$ & $(0.18,0.27,0.43)$ & $(1.00,1.00,1.00)$ \\
\hline
\end{tabular}

(2) Stage 2. Fuzzy AHP for determining the important weights of aspects and criteria

- Fuzzy synthetic extent calculation

With the help of Eq. (6), the values of fuzzy synthetic extent of three aspects can be obtained.

$$
\begin{gathered}
S_{1}=S_{E C}=(8.3333,11.6667,15.6667) \otimes\left(\frac{1}{24.3074}, \frac{1}{17.9825}, \frac{1}{13.1164}\right) \\
=(0.3428,0.6488,1.1944) \\
S_{2}=S_{E N}=(3.4638,4.8431,6.9394) \otimes\left(\frac{1}{24.3074}, \frac{1}{17.9825}, \frac{1}{13.1164}\right) \\
=(0.1425,0.2693,0.5291)
\end{gathered}
$$




$$
\begin{gathered}
S_{3}=S_{S O}=(1.3193,1.4727,1.7013) \otimes\left(\frac{1}{24.3074}, \frac{1}{17.9825}, \frac{1}{13.1164}\right) \\
=(0.0543,0.0819,0.1297)
\end{gathered}
$$

- Comparison of fuzzy values

Using Eq. (8), (9) to calculate the $V$ values. The degree of possibility of $S_{E N} \geq$ $S_{E C}$ can be calculated as

$$
V\left(S_{E N} \geq S_{E C}\right)=\frac{0.3428-0.5291}{(0.3428-0.5291)+(0.2693-0.6488)}=0.3292
$$

Similarly, other $V$ values can be calculated as shown in Table 8 .

Table 8. V values for aspects

\begin{tabular}{llll}
\hline Aspects & EC & EN & SO \\
\hline EC & $/$ & 1 & 1 \\
EN & 0.3292 & $/$ & 1 \\
SO & 0 & 0 & $/$ \\
\hline
\end{tabular}

- Priority weight calculation follows.

By using Eq. (12), the minimum degree of possibility can be obtained as

$$
d^{\prime}(E N)=\min V\left(S_{E N} \geq S_{E C}, S_{S O}\right)=\min (0.3292,1)=0.3292
$$

Similarly, $d_{E c}^{\prime}=1.0000 ; d_{S O}^{\prime}=0.0000$.

Then the weight vector is given with the help of Eq. (13)

$$
W^{\prime}=\left(d^{\prime}(E C), d^{\prime}(E N), d^{\prime}(S O)\right)^{T}=(1.0000,0.3292,0.0000)^{T}
$$

- Calculation of normalized weight vector

Finally, after normalization of $W^{\prime}$ by applying Eq. (14) and (15), the normalized weight vectors are determined as follows:

$$
W\left(A_{i}\right)=(0.7523,0.2477,0.0000)^{T}
$$

Thus, the normalized weights of three aspects are shown in Table 9.

Table 9. Weights of economic, environmental and social aspect

Aspects Fuzzy weight Normalized weight




\begin{tabular}{lll}
\hline EC & $(0.3428,0.6488,1.1944)$ & 0.7523 \\
EN & $(0.1425,0.2693,0.5291)$ & 0.2477 \\
SO & $(0.0543,0.0819,0.1297)$ & 0.0000 \\
\hline
\end{tabular}

Following the similar process as mentioned before, the weights of criterion Capital cost $\left(\mathrm{C}_{1}\right)$, Operational cost $\left(\mathrm{C}_{2}\right)$ and Life-cycle cost $\left(\mathrm{C}_{3}\right)$ are illustrated in Table 11.

Table 10. Aggregated fuzzy comparison matrix of criteria in economic aspect

\begin{tabular}{llll}
\hline Criteria & $\mathrm{C}_{1}$ & $\mathrm{C}_{2}$ & $\mathrm{C}_{3}$ \\
\hline $\mathrm{C}_{1}$ & $(1.00,1.00,1.00)$ & $(3.00,4.33,6.33)$ & $(3.67,5.67,7.67)$ \\
$\mathrm{C}_{2}$ & $(0.16,0.23,0.33)$ & $(1.00,1.00,1.00)$ & $(2.33,3.67,5.67)$ \\
$\mathrm{C}_{3}$ & $(0.13,0.18,0.27)$ & $(0.18,0.27,0.43)$ & $(1.00,1.00,1.00)$ \\
\hline
\end{tabular}

Table 11. Weights of criteria in economic aspect

\begin{tabular}{lll}
\hline Criteria & Fuzzy weight & Normalized weight \\
\hline $\mathrm{C}_{1}$ & $(0.3235,0.6341,1.2034)$ & 0.7124 \\
$\mathrm{C}_{2}$ & $(0.1473,0.2823,0.5616)$ & 0.2876 \\
$\mathrm{C}_{3}$ & $(0.0551,0.0835,0.1365)$ & 0.0000 \\
\hline
\end{tabular}

Similarly, the important weights of criterion Impact on $\mathrm{SO}_{\mathrm{x}}$ emissions reduction (C4), Impact on $\mathrm{NO}_{\mathrm{x}}$ emissions reduction ( $\mathrm{C}_{5}$ ), Impact on $\mathrm{GHG}$ emissions reduction (C6) and Impact on PM emissions reduction $\left(\mathrm{C}_{7}\right)$ are determined as shown in Table 13.

Table 12. Aggregated fuzzy comparison matrix of criteria in environmental aspect

\begin{tabular}{lllll}
\hline Criteria & $\mathrm{C}_{4}$ & $\mathrm{C}_{5}$ & $\mathrm{C}_{6}$ & $\mathrm{C}_{7}$ \\
\hline $\mathrm{C}_{4}$ & $(1.00,1.00,1.00)$ & $(5.00,7.00,8.33)$ & $(3.00,3.67,5.00)$ & $(5.00,7.00,8.33)$ \\
$\mathrm{C}_{5}$ & $(0.12,0.14,0.20)$ & $(1.00,1.00,1.00)$ & $(3.00,5.00,7.00)$ & $(2.33,3.00,5.00)$ \\
$\mathrm{C}_{6}$ & $(0.20,0.27,0.33)$ & $(0.14,0.20,0.33)$ & $(1.00,1.00,1.00)$ & $(3.00,5.00,7.00)$ \\
$\mathrm{C}_{7}$ & $(0.12,0.14,0.20)$ & $(0.20,0.33,0.43)$ & $(0.14,0.20,0.33)$ & $(1.00,1.00,1.00)$
\end{tabular}

Table 13. Weights of criteria in environmental aspect

Criteria

Fuzzy weight

Normalized weight 


\begin{tabular}{lll}
\hline $\mathrm{C}_{4}$ & $(0.3011,0.5191,0.8632)$ & 0.6619 \\
$\mathrm{C}_{5}$ & $(0.1388,0.2543,0.5027)$ & 0.2861 \\
$\mathrm{C}_{6}$ & $(0.0934,0.1800,0.3300)$ & 0.0520 \\
$\mathrm{C}_{7}$ & $(0.0315,0.0466,0.0747)$ & 0.0000 \\
\hline
\end{tabular}

Calculating the same way, the important weights of criterion Government and industry support $\left(\mathrm{C}_{8}\right)$ and Externalities $\left(\mathrm{C}_{9}\right)$ are presented Table 15.

Table 14. Aggregated fuzzy comparison matrix of criteria in social aspect

\begin{tabular}{lll}
\hline Criteria & $\mathrm{C}_{8}$ & $\mathrm{C}_{9}$ \\
\hline $\mathrm{C}_{8}$ & $(1.00,1.00,1.00)$ & $(1.67,2.33,3.67)$ \\
$\mathrm{C}_{9}$ & $(0.27,0.43,0.60)$ & $(1.00,1.00,1.00)$ \\
\hline
\end{tabular}

Table 15. Weights of criteria in social aspect

\begin{tabular}{lll}
\hline Criteria & Fuzzy weight & Normalized weight \\
\hline $\mathrm{C}_{8}$ & $(0.4255,0.7000,1.1846)$ & 1.0000 \\
$\mathrm{C} 9$ & $(0.2031,0.3000,0.4062)$ & 0.0000 \\
\hline
\end{tabular}

The global fuzzy weights of criterion $\mathrm{C}_{1}=$ the fuzzy weight of $\mathrm{C}_{1}$ in economic aspect $\otimes$ the normalized weight of economic aspect $=(0.3235,0.6341,1.2034) \otimes$ $0.7523=(0.2434,0.4771,0.9053)$. By doing the same way, Table 16 presents the global fuzzy weights of other criterion.

Table 16. Global fuzzy weight of criteria

\begin{tabular}{ll}
\hline Criteria & Global fuzzy weight \\
\hline $\mathrm{C}_{1}$ & $(0.2434,0.4771,0.9053)$ \\
$\mathrm{C}_{2}$ & $(0.1108,0.2124,0.4225)$ \\
$\mathrm{C}_{3}$ & $(0.0415,0.0629,0.1027)$ \\
$\mathrm{C}_{4}$ & $(0.0746,0.1286,0.2138)$ \\
$\mathrm{C}_{5}$ & $(0.0344,0.0630,0.1245)$ \\
$\mathrm{C}_{6}$ & $(0.0231,0.0446,0.0817)$ \\
$\mathrm{C}_{7}$ & $(0.0078,0.0115,0.0185)$ \\
$\mathrm{C}_{8}$ & $(0.0000,0.0000,0.0000)$
\end{tabular}


It can be seen from the results that the Social aspect is given a zero weight, resulting in global fuzzy weights of criteria $\mathrm{C}_{8}$ and $\mathrm{C}_{9}$ are also given zero weights. In the fuzzy AHP method, several criteria may be assigned irrational zero weights55, thus they are not considered in decision analysis. Given the input data for the fuzzy AHP mainly rely on experts' preferences, Social aspect is not evinced interest from shipowners compared to economic and environmental aspect. In the commercial cargo shipping industry, the protection of environment tends to be emphasized much more than human and social aspects under the corporate social responsibility (CSR) policies.56 Shipowners' ignorance of social aspect over economic and environmental aspects may explain why the criterion $\mathrm{C}_{8}$ and $\mathrm{C}_{9}$ are then not considered in the following evaluation procedure.

(3) Stage 3. Fuzzy TOPSIS for ranking alternatives

- Step 1. Aggregate the ratings of alternatives versus criteria

Decision makers were required to rate each alternative in respect of each criterion by using the linguistic variables as show in Table 17.

Table 17. Linguistic variables and the corresponding triangular fuzzy numbers for rating for alternatives in respect of criteria

\begin{tabular}{lll}
\hline Linguistic variables & Code & Triangular fuzzy numbers \\
\hline Very poor & VP & $(0.0,0.1,0.2)$ \\
Poor & P & $(0.1,0.3,0.5)$ \\
Fair & F & $(0.3,0.5,0.7)$ \\
Good & G & $(0.5,0.7,0.9)$ \\
Very good & VG & $(0.8,0.9,1.0)$ \\
\hline
\end{tabular}

The input of experts along with aggregated suitability ratings of four alternatives by using Eq. (16) are given in Table 18. 


\begin{tabular}{|c|c|c|c|c|c|}
\hline \multirow{2}{*}{ Criteria } & \multirow{2}{*}{ Alternatives } & \multicolumn{3}{|c|}{ Decision makers } & \multirow{2}{*}{$r_{i j}$} \\
\hline & & $\mathrm{DM}_{1}$ & $\mathrm{DM}_{2}$ & $\mathrm{DM}_{3}$ & \\
\hline \multirow{4}{*}{$\mathrm{C}_{1}$} & $\mathrm{~A}_{1}$ & VG & $\mathrm{G}$ & VG & $(0.700,0.833,0.967)$ \\
\hline & $\mathrm{A}_{2}$ & $\mathrm{~F}$ & $\mathrm{P}$ & $\mathrm{F}$ & $(0.233,0.433,0.633)$ \\
\hline & $\mathrm{A}_{3}$ & VP & VP & $\mathrm{P}$ & $(0.033,0.167,0.300)$ \\
\hline & $\mathrm{A}_{4}$ & $\mathrm{~F}$ & $\mathrm{~F}$ & $\mathrm{~F}$ & $(0.300,0.500,0.700)$ \\
\hline \multirow{4}{*}{$\mathrm{C}_{2}$} & $\mathrm{~A}_{1}$ & $\mathrm{P}$ & $\mathrm{G}$ & $\mathrm{P}$ & $(0.233,0.433,0.633)$ \\
\hline & $\mathrm{A}_{2}$ & $\mathrm{G}$ & VG & $\mathrm{G}$ & $(0.600,0.767,0.933)$ \\
\hline & $\mathrm{A}_{3}$ & $\mathrm{P}$ & $\mathrm{G}$ & G & $(0.367,0.567,0.767)$ \\
\hline & $\mathrm{A}_{4}$ & $\mathrm{P}$ & $\mathrm{G}$ & $\mathrm{P}$ & $(0.233,0.433,0.633)$ \\
\hline \multirow{4}{*}{$\mathrm{C}_{3}$} & $\mathrm{~A}_{1}$ & $\mathrm{G}$ & $\mathrm{P}$ & $\mathrm{F}$ & $(0.300,0.500,0.700)$ \\
\hline & $\mathrm{A}_{2}$ & $\mathrm{~F}$ & $\mathrm{~F}$ & $\mathrm{G}$ & $(0.367,0.567,0.767)$ \\
\hline & $\mathrm{A}_{3}$ & $\mathrm{P}$ & $\mathrm{P}$ & $\mathrm{P}$ & $(0.100,0.300,0.500)$ \\
\hline & $\mathrm{A}_{4}$ & $\mathrm{~F}$ & $\mathrm{~F}$ & $\mathrm{P}$ & $(0.233,0.433,0.633)$ \\
\hline \multirow{4}{*}{$\mathrm{C}_{4}$} & $\mathrm{~A}_{1}$ & $\mathrm{G}$ & $\mathrm{G}$ & $\mathrm{F}$ & $(0.433,0.633,0.833)$ \\
\hline & $\mathrm{A}_{2}$ & $\mathrm{G}$ & $\mathrm{G}$ & $\mathrm{F}$ & $(0.433,0.633,0.833)$ \\
\hline & $\mathrm{A}_{3}$ & VG & VG & VG & $(0.800,0.900,1.000)$ \\
\hline & $\mathrm{A} 4$ & VG & VG & VG & $(0.800,0.900,1.000)$ \\
\hline \multirow{4}{*}{$\mathrm{C}_{5}$} & $\mathrm{~A}_{1}$ & VP & $\mathrm{P}$ & $\mathrm{P}$ & $(0.067,0.233,0.400)$ \\
\hline & $\mathrm{A}_{2}$ & VP & $\mathrm{P}$ & $\mathrm{P}$ & $(0.067,0.233,0.400)$ \\
\hline & $\mathrm{A}_{3}$ & $\mathrm{~F}$ & $\mathrm{G}$ & $\mathrm{G}$ & $(0.433,0.633,0.833)$ \\
\hline & $\mathrm{A}_{4}$ & $\mathrm{~F}$ & $\mathrm{G}$ & $\mathrm{G}$ & $(0.433,0.633,0.833)$ \\
\hline \multirow{4}{*}{$\mathrm{C}_{6}$} & $\mathrm{~A}_{1}$ & VP & $\mathrm{P}$ & $\mathrm{P}$ & $(0.067,0.233,0.400)$ \\
\hline & $\mathrm{A}_{2}$ & VP & $\mathrm{P}$ & $\mathrm{P}$ & $(0.067,0.233,0.400)$ \\
\hline & $\mathrm{A}_{3}$ & $\mathrm{P}$ & $\mathrm{F}$ & $\mathrm{G}$ & $(0.300,0.500,0.700)$ \\
\hline & $\mathrm{A}_{4}$ & $\mathrm{~F}$ & $\mathrm{P}$ & $\mathrm{P}$ & $(0.167,0.367,0.567)$ \\
\hline
\end{tabular}




\begin{tabular}{|c|c|c|c|c|c|}
\hline \multirow{4}{*}{$\mathrm{C}_{7}$} & $\mathrm{~A}_{1}$ & $\mathrm{~F}$ & $\mathrm{~F}$ & $\mathrm{~F}$ & $(0.300,0.500,0.700)$ \\
\hline & $\mathrm{A}_{2}$ & $\mathrm{~F}$ & $\mathrm{~F}$ & G & $(0.367,0.567,0.767)$ \\
\hline & $\mathrm{A}_{3}$ & VG & $\mathrm{G}$ & VG & $(0.700,0.833,0.967)$ \\
\hline & $\mathrm{A}_{4}$ & VG & $\mathrm{VG}$ & VG & $(0.800,0.900,1.000)$ \\
\hline \multirow{4}{*}{$\mathrm{C}_{8}$} & $\mathrm{~A}_{1}$ & $\mathrm{G}$ & $\mathrm{G}$ & G & $(0.500,0.700,0.900)$ \\
\hline & $\mathrm{A}_{2}$ & $\mathrm{G}$ & $\mathrm{F}$ & $\mathrm{F}$ & $(0.367,0.567,0.767)$ \\
\hline & $\mathrm{A}_{3}$ & VG & VG & VG & $(0.800,0.900,1.000)$ \\
\hline & $\mathrm{A}_{4}$ & VG & $\mathrm{G}$ & VG & $(0.700,0.833,0.967)$ \\
\hline \multirow{4}{*}{$\mathrm{C}_{9}$} & $\mathrm{~A}_{1}$ & $\mathrm{G}$ & $\mathrm{G}$ & G & $(0.500,0.700,0.900)$ \\
\hline & $\mathrm{A}_{2}$ & $\mathrm{~F}$ & $\mathrm{~F}$ & $\mathrm{~F}$ & $(0.300,0.500,0.700)$ \\
\hline & $\mathrm{A}_{3}$ & VG & $\mathrm{VG}$ & VG & $(0.800,0.900,1.000)$ \\
\hline & $\mathrm{A}_{4}$ & $\mathrm{G}$ & $\mathrm{G}$ & VG & $(0.600,0.767,0.933)$ \\
\hline
\end{tabular}

- Step 2. Normalize performance of alternatives versus criteria

It is unnecessary to normalize the averaged ratings of alternatives in regard to criteria into comparable values compatible with the weights of criteria since all the fuzzy numbers of performance values are in the range of $[0,1]$.

- Step 3. Calculate normalized weighted rating

The normalized weighted ratings $G_{i}$ can be obtained by applying Eq. (18) as demonstrated in Table 19.

Table 19. Normalized weighted ratings of each alternatives

\begin{tabular}{ll}
\hline Alternatives & Normalized weighted ratings $\boldsymbol{G}_{\boldsymbol{i}}$ \\
\hline A1 & $(0.0353,0.0905,0.2126)$ \\
$\mathrm{A} 2$ & $(0.0254,0.0740,0.1888)$ \\
$\mathrm{A} 3$ & $(0.0200,0.0580,0.1485)$ \\
A4 & $(0.0276,0.0772,0.1927)$ \\
\hline
\end{tabular}

- Step 4. Calculate distances 
The distance of each alternative from the FPIS $A^{+}$and NPIS $A^{-}$can be determined with the help of Eq. (19), (20) as given in Table 20.

Table 20. The distance of each alternative from the FPIS $A^{+}$and NPIS $A^{-}$

\begin{tabular}{lll}
\hline Alternatives & $\boldsymbol{d}^{+}$ & $\boldsymbol{d}^{-}$ \\
\hline $\mathrm{A} 1$ & 1.5420 & 0.2337 \\
$\mathrm{~A} 2$ & 1.5702 & 0.2043 \\
$\mathrm{~A} 3$ & 1.6040 & 0.1607 \\
$\mathrm{~A} 4$ & 1.5649 & 0.2094 \\
\hline
\end{tabular}

- Step 5. Calculate the closeness coefficient

The closeness coefficient of alternatives can be obtained by using Eq. (21) as shown in Table 21. The ranking of alternatives in descending order is $\mathrm{A}_{1}>\mathrm{A}_{4}>\mathrm{A}_{2}>$ A3.

Table 21. The closeness coefficient of alternatives $C C_{i}$

\begin{tabular}{lll}
\hline Alternatives & Closeness coefficient $\boldsymbol{C} \boldsymbol{C}_{\boldsymbol{i}}$ & Ranking \\
\hline $\mathrm{A}_{1}$ & 0.1316 & 1 \\
$\mathrm{~A} 2$ & 0.1151 & 3 \\
$\mathrm{~A} 3$ & 0.0911 & 4 \\
$\mathrm{~A} 4$ & 0.1180 & 2 \\
\hline
\end{tabular}

(4) Stage 4. Validation

In this stage, we applied the sensitivity analysis in order to elaborate the sensitivity of the alternatives prioritization in respect of changing priority weights of criteria. In order words, the implementation of sensitivity analysis aimed to see how the changes of criteria weights affect the alternatives prioritization. As mentioned in the previous stage, the criterion $\mathrm{C}_{8}$ and $\mathrm{C}_{9}$ were removed from the decision-making process. Taking the original outcomes as the base scenario, 21 scenarios were produced by changing the criteria weights sequentially. As a result, $C C_{i}$ values for alternatives were changed accordingly. Figure 4 reveals graphically the results of sensitivity analysis.

As can be observed from the sensitivity analysis, alternative A1 which took the lead in the base scenario, still maintained its spot in 15 scenarios out of 21 scenarios, accounting for approximately $71 \%$. Apart from these scenarios, alternative $\mathrm{A}_{2}$ takes the lead in two scenarios number 2 and 3 , whereas alternative $\mathrm{A}_{4}$ is the winner in scenarios number 4. In the remaining scenarios number 5, 6 and 7, alternative $A_{3}$ reaches the top. These striking changes are attributed to the fact that the weight of the criterion $\mathrm{C}_{1}$ was 
exchanged with the respective criteria. Hence, it can be concluded that the first criterion $\mathrm{C}_{1}$ is the most influential in the proposed framework.

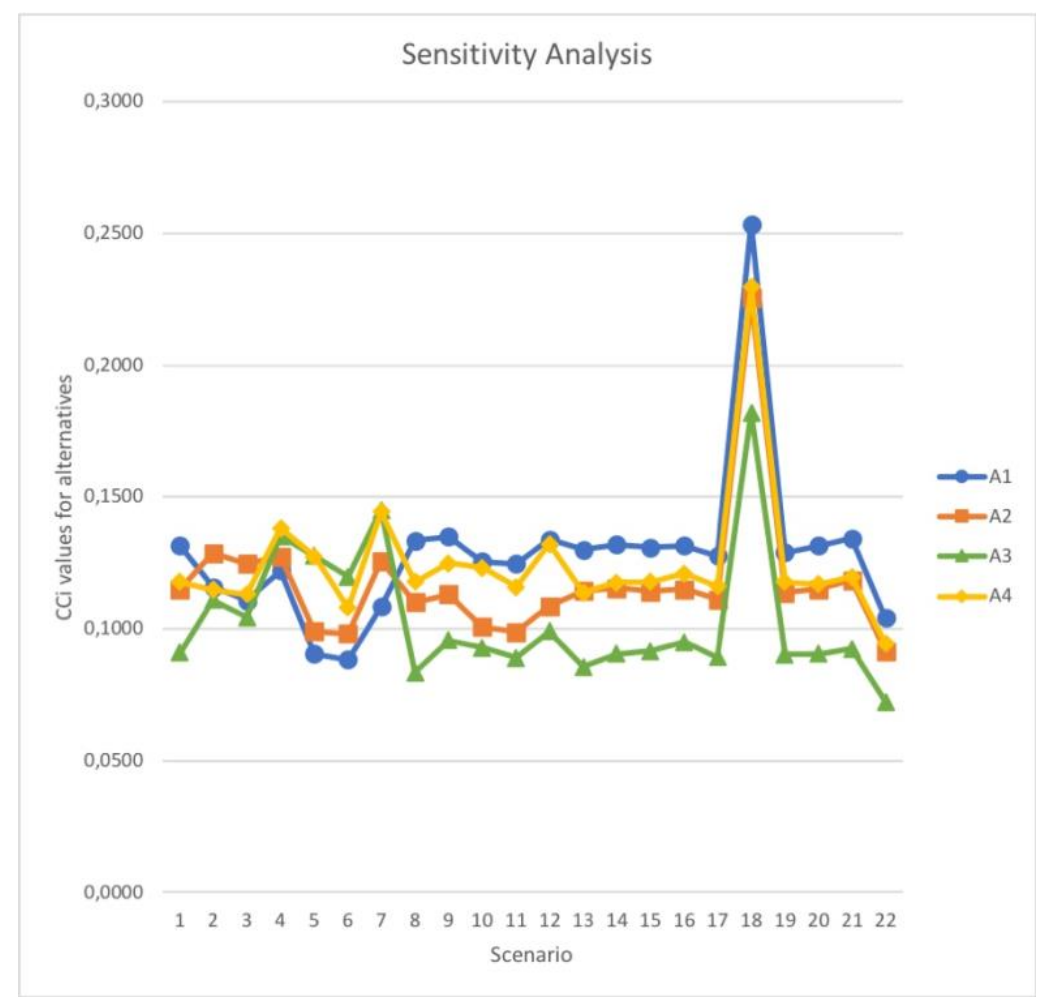

Figure 4. Sensitivity analysis results

\section{Discussion and conclusion}

\subsection{Results and discussion}

Among three sustainability aspects, the economic aspect was found to be the most preferable by the decision makers compared to environmental and social aspect. It is not surprising since the profitability attaches the most attention of decision makers (shipowners and operators). In the economic aspect, the capital cost played a pivotal role when considering the selection of technological alternatives to meet tightening regulations. The impact on $\mathrm{SO}_{\mathrm{x}}$ reduction criteria attracted the highest priority in environmental aspect, followed by the impact on $\mathrm{NO}_{\mathrm{x}}$ reduction criteria. This is attributed to the existing regulation on sulphur emissions (sulphur emissions limit of $0.1 \%$ within ECAs and the 2020 global sulphur emissions limit of $0.5 \%$ ) as well as $\mathrm{NO}_{\mathrm{x}}$ emissions regulation (Tier III) for new-build ships in ECAs. The impact on GHG reduction and the impact on PM reduction criteria were not given the shipowners' interest because the Paris Climate Agreement does not impose penalties on GHG emissions from the shipping industry and there are no regulations on PM emissions yet. There is increasing concerns for the marine environment and new measures have been and will be implemented continuously to preserve the oceans and seas. It is critical to emphasize that in the future, there will be stricter legislations on GHG emissions from the maritime industry even with low-sulphur and low-nitrogen fuels.

Based on the $C C_{i}$ values, the study showed that the prioritization of the alternative technologies was Low-Sulphur Fuels, Methanol, HFO with scrubbers and LNG from the most preferable to the least preferable. The results of alternative ranking reflect the current situation of shipping industry in which inertia and financial issues are 
taken into account. Low-sulphur fuels are likely to be a mainstream solution for regulatory compliance in terms of the 2020 global sulphur limit.57 Furthermore, the results are also in line with the results of some studies in literature, in which Lowsulphur fuels are considered as the best option in the short-term.17, 34 In the medium and long run, shipowners and operators should consider potential future regulatory changes and actual conditions to decide on which path they should follow based on their preferable interest.

The outcomes of sensitivity analysis indicated that the weight of the criterion Capital cost $\left(\mathrm{C}_{1}\right)$ has significant impact on the prioritization of alternatives. The reason behind this impact was the high decision-makers' preferences over this criterion. It is undeniable that capital cost is the most important factor of ship operators when it comes to investment decision on selecting emissions reduction measures.

\subsection{Conclusion}

The selection of alternative options towards reducing harmful emissions produced by ships is regarded as MCDM issue which refers to the prioritization of several feasible alternatives vis-à-vis multi-criteria evaluation. It is more challenging for decision makers when they deal with fuzzy environment of vague, incomplete and inconsistent information. This study developed the integrated fuzzy MCDM approach that combines the fuzzy AHP and fuzzy TOPSIS techniques. The proposed fuzzy approach after that was applied on a real study case by engaging ship-owners as decision makers. Their involvement and interactions were considered in two phases. First, after identifying and evaluating criteria and feasible alternatives, they were requested to decide the priority weightings of aspects as well as criteria by pairwise comparison. Second, they were required to rate the performances of alternatives in respect of criteria. The weights of assessed criteria produced by the fuzzy AHP were used as inputs in the fuzzy TOPSIS. The linguistic evaluation variables were employed to ensure the evaluation procedure more realistic since it has fuzziness and incompleteness in its nature. Nine criteria in three aspects along with four feasible alternatives are mentioned in the proposed method, aiming at prioritizing the alternative options from the most preferred to the least preferred. According to results of the study, Low-Sulphur Fuels took the lead, followed by Methanol. Scrubbers and LNG were the third and fourth solution respectively. The deployment of sensitivity analysis depicted that the proposed decision-making framework is robust except for the changes of the weight of criterion Capital cost with another criterion.

This study proposed the comprehensive and holistic integrated fuzzy MCDM approach to overcome the hurdle of multi-criteria decision making under fuzzy environment. This approach can be potentially applicable to other research fields as a useful decision-support tool for decision-makers to make decision under vague information conditions. As regards the limitation of this study, the outcomes of the study could be valid for the short-run setup with the timespan of the next few years. For the future situation (e.g., in 2030 or 2050), there will be much uncertainty surrounding the problem of emissions compliance. There are several aspects and factors as well as the next generation of technologies and future new alternative fuels (i.e. the utilization of fuel cells, batteries and hydrogen, ammonia respectively) that have not discussed and not incorporated in the proposed decision-making process yet. Furthermore, with the uptake of LNG that will reach a maximum of 11 percent share by 2030 and its affordability58, the situation might change. Future energy security related developments also exert an impact on the selection of today regulatory compliance alternatives. 
Therefore, the maritime industry is dealing with the problem of making the right decision under uncertainty conditions. At the moment, many ship owners have been waiting to see which direction the shipping industry takes before making their own decisions on technology investment.

The proposed method also has several following drawbacks. Firstly, the fuzzy AHP may involve the subjectivity of decision makers in their judgements on criteria weightings. Hence, the quality of experts with their expertise and experience play a vital role when evaluating the criteria in the proposed methodology since experts with different backgrounds and perspectives may display different viewpoints, leading to bias in input data. Secondly, the fuzzy AHP technique may assign unreasonable zero weights to decision criteria attributed to the peculiarity of the method. However, the fuzzy AHP has still been widely used in the literature. Future research work plans to enhance the fuzzy AHP with other techniques to transcend its limitation. Another potential research area would be comparison between MCDM techniques and utilization of advanced-MCDM method in complex application.

\section{Acknowledgements}

The authors wish to record our deepest appreciation towards ship owners with their anonymity for being generous with their time attending face-to-face interviews with us to provide input data for this study. We are profoundly thankful the anonymous reviewers for their valuable feedback in order to improve and enrich the quality of this work.

\section{Declaration of Conflicting Interests}

The authors declare that there is no conflict of interest as regards the research, authorship and/or publication of this article.

\section{Funding}

The authors received no financial support for the research, authorship and/or publication of this article. 


\section{REFERENCES}

1. Smith T, P. Jalkanen J, A. Anderson B, et al. Third IMO GHG Study 2014: Executive Summary and Final Report. Report no. First presented to Marine Environment Protection Committee 67 as MEPC 67/INF.3, 2014. International Maritime Organization.

2. Eyring V, Isaksen ISA, Berntsen T, et al. Transport impacts on atmosphere and climate: Shipping. Atmospheric Environment 2010; 44: 4735-4771. DOI: https://doi.org/10.1016/j.atmosenv.2009.04.059.

3. Bazari Z. IMO Train the Trainer (TTT) Course on Energy Efficient Ship Operation Module 2 - Ship Energy Efficiency Regulations and Related Guidelines. January 2016 ed. London: International Maritime Organization, 2016.

4. IMO. UN body adopts climate change strategy for shipping. International Maritime Organization (IMO), 2018.

5. IMO. IMO sets 2020 date for ships to comply with low sulphur fuel oil requirement. International Maritime Organization (IMO), 2016.

6. IMO. Implementation of sulphur 2020 limit - carriage ban adopted. International Maritime Organization (IMO), 2018.

7. IMO. Marine Environment Protection Committee (MEPC), 70th session, 2428 October 2016. International Maritime Organization (IMO), 2016.

8. Ölçer Aİ and Odabaşi AY. A new fuzzy multiple attributive group decision making methodology and its application to propulsion/manoeuvring system selection problem. European Journal of Operational Research 2005; 166: 93-114. DOI: https://doi.org/10.1016/j.ejor.2004.02.010.

9. Shih H-S, Shyur H-J and Lee ES. An extension of TOPSIS for group decision making. Mathematical and Computer Modelling 2007; 45: 801-813. DOI: https://doi.org/10.1016/j.mcm.2006.03.023.

10. Zadeh LA. The concept of a linguistic variable and its application to approximate reasoning-I. Information Sciences 1975; 8: 199-249. DOI: https://doi.org/10.1016/0020-0255(75)90036-5.

11. Zadeh LA. The concept of a linguistic variable and its application to approximate reasoning-II. Information Sciences 1975; 8: 301-357. DOI: https://doi.org/10.1016/0020-0255(75)90046-8.

12. Wang Chen HM, Chou S-Y, Luu QD, et al. A Fuzzy MCDM Approach for Green Supplier Selection from the Economic and Environmental Aspects. Mathematical Problems in Engineering 2016; 2016: 10. DOI: 10.1155/2016/8097386. 13. Saaty RW. The analytic hierarchy process - what it is and how it is used. Mathematical Modelling 1987; 9: 161-176. DOI: https://doi.org/10.1016/02700255(87)90473-8.

14. Schinas O and Stefanakos CN. Selecting technologies towards compliance with MARPOL Annex VI: The perspective of operators. Transportation Research Part D: Transport and Environment 2014; 28: 28-40. DOI: https://doi.org/10.1016/j.trd.2013.12.006.

15. Yang ZL, Zhang D, Caglayan O, et al. Selection of techniques for reducing shipping NOx and SOx emissions. Transportation Research Part D: Transport and Environment 2012; 17: 478-486. DOI: https://doi.org/10.1016/j.trd.2012.05.010.

16. Ölçer A and Ballini F. The development of a decision making framework for evaluating the trade-off solutions of cleaner seaborne transportation. Transportation Research Part D: Transport and Environment 2015; 37: 150-170. DOI: https://doi.org/10.1016/j.trd.2015.04.023. 
17. Ren $\mathbf{J}$ and Lützen $\mathrm{M}$. Fuzzy multi-criteria decision-making method for technology selection for emissions reduction from shipping under uncertainties. Transportation Research Part D: Transport and Environment 2015; 40: 43-60. DOI: https://doi.org/10.1016/j.trd.2015.07.012.

18. Wang $\mathrm{H}$ and Nguyen S. Prioritizing mechanism of low carbon shipping measures using a combination of FQFD and FTOPSIS. Maritime Policy \& Management 2017; 44: 187-207. DOI: 10.1080/03088839.2016.1245878.

19. Beşikçi EB, Kececi T, Arslan O, et al. An application of fuzzy-AHP to ship operational energy efficiency measures. Ocean Engineering 2016; 121: 392-402. DOI: https://doi.org/10.1016/j.oceaneng.2016.05.031.

20. Ren J and Lützen M. Selection of sustainable alternative energy source for shipping: Multi-criteria decision making under incomplete information. Renewable and Sustainable Energy Reviews 2017; 74: 1003-1019. DOI: https://doi.org/10.1016/j.rser.2017.03.057.

21. Ren $\mathbf{J}$ and Liang $\mathrm{H}$. Measuring the sustainability of marine fuels: A fuzzy group multi-criteria decision making approach. Transportation Research Part D: Transport and Environment 2017; 54: 12-29. DOI: https://doi.org/10.1016/j.trd.2017.05.004.

22. Sahin B and Yip TL. Shipping technology selection for dynamic capability based on improved Gaussian fuzzy AHP model. Ocean Engineering 2017; 136: 233 242. DOI: https://doi.org/10.1016/j.oceaneng.2017.03.032.

23. Andersson K, Brynolf S, Lindgren J, et al. Shipping and the Environment Improving Environmental Performance in Marine Transportation. 2016.

24. Deniz C and Zincir B. Environmental and economical assessment of alternative marine fuels. Journal of Cleaner Production 2016; 113: 438-449. DOI: https://doi.org/10.1016/j.jclepro.2015.11.089.

25. Gratsos GA and Zachariadis P. Life cycle cost of maintaining the effectiveness of a ship's structure and environmental impact of ship design parameters. RINA International conference on the Design and Operation of Bulk Carriers. London 2005, p. 95-122.

26. Vestreng V, Myhre G, Fagerli H, et al. Twenty-five years of continuous sulphur dioxide emission reduction in Europe. Atmos Chem Phys 2007; 7: 3663-3681. DOI: 10.5194/acp-7-3663-2007.

27. Pleijel H. Air pollution \& climate change, Two sides of the same coin? Stockholm: Swedish Environmental Protection Agency, 2009.

28. WHO. Air quality guidelines. Global update 2005. Particulate matter, ozone, nitrogen dioxide and sulfur dioxide. World Health Organization, 2006.

29. EU. Proposal for a COUNCIL DECISION on the position to be adopted on behalf of the European Union at the International Maritime Organization during the 66th session of the Marine Environment Protection Committee on the adoption of amendments to MARPOL Annex VI concerning the delay of the Tier III NOx emission standards Brussels: European Commission, 2014.

30. EU. External costs: Research results on socio-environmental damages due to electricity and transport. Brussels: European Commission, 2003.

31. $\mathrm{Ng} \mathrm{AKY}$ and Song S. The environmental impacts of pollutants generated by routine shipping operations on ports. Ocean \& Coastal Management 2010; 53: 301311. DOI: https://doi.org/10.1016/j.ocecoaman.2010.03.002.

32. Burel F, Taccani R and Zuliani N. Improving sustainability of maritime transport through utilization of Liquefied Natural Gas (LNG) for propulsion. Energy 2013; 57: 412-420. DOI: https://doi.org/10.1016/j.energy.2013.05.002. 
33. Winnes $\mathrm{H}$. Exhaust gas $\mathrm{SO} 2$ scrubbers and the environment. IVL Swedish Environmental Research Institute, 2017.

34. Helfre J-F and Boot PAC. Emission Reduction in the Shipping Industry: Regulations, Exposure and Solutions. 2013. Sustainalytics.

35. ITF. Reducing Sulphur Emissions from Ships: The Impact of International Regulation. Corporate Partnership Board Report. 9 May 2016. The International Transport Forum.

36. Acciaro M. Real option analysis for environmental compliance: LNG and emission control areas. Transportation Research Part D: Transport and Environment 2014; 28: 41-50. DOI: https://doi.org/10.1016/j.trd.2013.12.007.

37. Simmer L, Aschauer G, Schauer O, et al. LNG as an alternative fuel: The steps towards European implementation. 2014, p.887-898.

38. EMSA. The 0.1\% sulphur in fuel requirement as from 1 January 2015 in SECAs - An assessment of available impact studies and alternative means of compliance. 13 December 2010. The European Maritime Safety Agency (EMSA).

39. Ellis J and Tanneberger K. Study on the use of ethyl and methyl alcohol as alternative fuels in shipping. 2015. The European Maritime Safety Agency (EMSA).

40. Notteboom T. The impact of low sulphur fuel requirements in shipping on the competitiveness of roro shipping in Northern Europe. WMU Journal of Maritime Affairs 2011; 10: 63-95. DOI: 10.1007/s13437-010-0001-7.

41. DNVGL. GLOBAL SULPHUR CAP 2020 Know the different choices and challenges for on-time compliance. 2016. DNV GL.

42. CNSS. LNG fuelled ships as a contribution to clean air in harbours. CNSS Work package 4, Showcase LNG. 2013. Clean North Sea Shipping (CNSS).

43. Hoen Mt and Boer Ed. Scrubbers - An economic and ecological assessment. March 2015. CE Delft.

44. Wärtsilä. LNG as a marine fuel: boosts profitability while ensuring compliance. Business White Paper. 2017. Wärtsilä.

45. IMO. Studies on the feasibility and use of LNG as a fuel for shipping. 2016. The International Maritime Organization (IMO).

46. Hapag-Lloyd. Hapag-lloyd establishes marine fuel recovery (MFR) mechanism. Hapag-Lloyd, 2018.

47. EGCSA. Scrubber orders full ahead. Exhaust Gas Cleaning Systems Association (EGCSA), 2018.

48. Nilsen OV. Reviewing the Current and Future LNG Regulatory Landscape. LNG: BEST FUEL OF THE FUTURE. Bergen, Norway 2018.

49. Svanberg M, Ellis J, Lundgren J, et al. Renewable methanol as a fuel for the shipping industry. Renewable and Sustainable Energy Reviews 2018; 94: 1217-1228. DOI: https://doi.org/10.1016/j.rser.2018.06.058.

50. Dubois D and Prade H. Operations on fuzzy numbers. International Journal of Systems Science 1978; 9: 613-626. DOI: 10.1080/00207727808941724.

51. Kaufmann A and Gupta M. Introduction to Fuzzy Arithmetic: Theory and Applications. 1986.

52. Khazaeni G, Khanzadi M and Afshar A. Fuzzy adaptive decision making model for selection balanced risk allocation. 2012; 30. DOI: 10.1016/j.ijproman.2011.10.003.

53. Chang D-Y. Applications of the extent analysis method on fuzzy AHP. European Journal of Operational Research 1996; 95: 649-655. DOI: https://doi.org/10.1016/0377-2217(95)00300-2. 
54. Mokhtari K, Ren J, Roberts C, et al. Decision support framework for risk management on sea ports and terminals using fuzzy set theory and evidential reasoning approach. 2012; 39: 5087-5103. DOI: 10.1016/j.eswa.2011.11.030.

55. Wang Y-M, Luo Y and Hua Z. On the extent analysis method for fuzzy AHP and its applications. 2008; 186: 735-747. DOI: 10.1016/j.ejor.2007.01.050.

56. Sampson H. "Seabirds Matter More Than Us!": Understanding the Complex Exercise of CSR in the Global Shipping Industry. The Journal of Sustainable Mobility 2016; 3: 101-119(119). DOI: https://doi.org/10.9774/GLEAF.2350.2016.de.00007.

57. Jordan J and Hickin P. Tackling 2020: the impact of the IMO and how shipowners can deal with tighter sulfur limits. Shipping special report. 2017.

58. Global Marine Fuels Trends 2030. 2014. Lloyd's Register Marine

University College London's Energy Institute. 